\title{
Noodle Development and Its Quality Characteristics Using Fermented White and Brown Rice
}

\author{
Min Jeong Seo', Byoung Won Kang', Jeong Uck Park', Min Jeong Kim², Hye Hyeon Lee $^{2}$ and \\ Yong Kee Jeong ${ }^{1,2} *$
}

\author{
${ }^{1}$ Medi-Farm Industrialization Research Center, Dong-A University, Busan 604-714, Korea \\ ${ }^{2}$ Department of Biotechnology, Dong-A University, Busan 604-714, Korea
}

Received August 17, 2012 /Revised October 8, 2012 /Accepted October 9, 2012

\begin{abstract}
To address the limitations of manufacturing noodle products using rice, brown rice noodles were created by the fermentation of brown rice containing several nutrients and the quality of these noodles were evaluated. White rice noodles, fermented white rice noodles, brown rice noodles, and fermented brown rice noodles were developed using white rice and brown rice, respectively. We found that the content of crude proteins present in the noodles during the fermentation process increased and the content of crude fat and carbohydrates in the noodles was reduced. In addition, the water content of brown rice noodles was twofold higher than that of white rice, although under fermentation conditions, the water content of brown rice noodles decreased slightly. A slight change of chromaticity was observed during the fermentation process. In cooking, the weight and volume of the noodles increased, with the change being lowest in noodles based on white rice. White rice-based noodles exhibited significantly higher turbidity in the cooked noodle soup, while other noodle products showed relatively constant turbidity. Most of the products showed a decreased texture, becoming soft with cooking; however, the elasticity of the cooked products increased. Our results suggest that the disadvantages of producing rice noodles can be overcome by the development of fermented brown rice noodles containing a variety of nutritional components. This would potentially develop a market for rice-based manufactured foods that appeal to modern preferences.
\end{abstract}

Key words : Brown rice, fermentation, noodle, white rice

\section{서 론}

쌀은 아시아를 대표하는 곡식으로 오래 전부터 주식으로 이용되어 왔으며, 쌀을 주식으로 하는 사람들의 대부분 영양 원이 되었다. 쌀은 도정도에 따라 현미, 5 분도미, 7 분도미, 백 미(10분도미)로 나누어지는데, 일반 영양성분은 쌀의 품종, 재 배지역 등에 따라 다소 차이가 있으나 백미의 경우 가식부 대부분이 전분으로서 약 $76.8 \%$, 단백질 $6.8 \%$, 지방 $1.0 \%$, 조섬 유 $0.7 \%$ 등으로 구성되어 있고, 무기질로서는 인과 칼륨, 칼슘, 마그네슘, 나트륨, 철분이 함유되어 있다. 또한 쌀에는 비타민 $\mathrm{B}_{1}$ (thiamin), 비타민 $\mathrm{B}_{2}$ (riboflavin), 비타민 D, 비타민 E, 엽산 등 인체에 중요한 비타민을 공급한다. 그리고 쌀은 단백질 공 급원으로써 중요한 역할을 하는데 아미노산 조성 중 필수아미 노산인 라이신(lysine) 함량이 옥수수, 조, 밀가루에 비하여 2 배 정도 높다. 특히 현미는 단백질, 지방 등의 비 전분질 인자 들이 백미보다 많이 함유되어 있어 무기질의 공급원으로도 매우 중요하다[21]. 또한 쌀의 지방은 대부분 산화되기 쉬운

\footnotetext{
*Corresponding author

Tel : +82-51-200-7557, Fax : +82-51-206-0848

E-mail : ykj9912@dau.ac.kr
}

불포화지방산으로 구성되어 있으나 현미 중에 포함된 ferulic acid 같은 강한 항산화제가 다량 함유되어 있어 쉽게 산화하지 않는 것으로 알려져 있다 $[5,14,15]$. 이러한 영양성분을 가지는 쌀의 생리활성 성분의 기능적 연구는 상대적으로 미미한 상태 이며, 항혈전 및 항산화, 항돌연변이 활성이 보고되어 있다 $[2,10,15,20]$. 이러한 생리기능성을 가진 쌀은 최근 식생활의 서구화에 따라 밀을 이용한 다양한 식품으로 인하여 그 소비 가 점점 감소하고 있는 추세이다. 따라서 쌀의 이용한 다양한 가공식품의 개발의 필요성이 절실히 대두되는 실정이다.

국수는 곡물의 가루를 반죽하여 가늘고 길게 뽑은 식품을 총칭하는 우리말로서 면(麵)이라고 한다. 국수는 세계적으로 널리 분포되어 있는 분식형 식품으로 밀가루 외에 쌀, 메밀가 루, 전분가루 등이 국수의 재료로 이용된다[23]. 특히 면 가공 식품은 대부분 밀가루를 이용한 것이 대부분이며, 최근 웰빙 식품을 선호함에 따라 밀에 산마늘[17], 연입분말[16], 매생이 가루[9] 등을 이용하여 기능성 성분을 첨가된 면 제품을 제조 하며, 또한 다양한 기능성영양성분을 함유한 쌀을 이용하여 면 가공식품을 제조하고 있다. 하지만 쌀을 이용하여 면 제조 시에 어려움이 있는데, 국수의 원료인 밀가루를 대신 이용하 는 경우 면의 탄력성을 가지게 하는 글루텐이 없어서 면대 
형성이 매우 힘들며 밀가루 국수가 갖는 독특한 질감을 얻기 가 어려운 단점이 있다. 따라서 쌀가루를 이용한 면제품은 국 수, 라면 등에 쌀가루를 10 30\% 첨가하여 제조하는 수준에서 최근 쌀 $100 \%$ 를 이용한 생면 및 indica 품종을 이용한 베트남 쌀국수 타임으로 쌀 함량이 높아지고 있으나 쌀 고유의 특성 으로 면의 가공이 어려우며, 조리시 전분의 용출량이 많아 이 를 개선하기 위한 쌀을 이용한 면제품개발이 계속적으로 이루 어지고 있다[4,11].

최근 다양한 식품을 선호하는 소비자 기호도에 맞추어 면 류시장은 점점 증가하는 추세이다. 특히 영양학적 성분을 고 려한 제품 및 조직감 등의 변화를 최소한 제품의 개발과 더 불어 조리시간을 단축할 수 있는 편리성은 면류의 선호도를 증대시키고 있다[18,19]. 본 연구에서는 쌀을 이용하여 면류 의 개발에서 쌀보다는 영양학적인 성분이 우수한 현미를 이 용하여 면제품을 개발하고자 하였으며, 면류의 개발에 있어 서는 발효과정을 통하여 미생물에 의하여 쌀국수가 가지는 단점을 개선하고자 하였다. 따라서 현미를 발효하여 발효 현 미국수를 제조하였으며, 제조된 발효 현미국수의 품질특성 을 확인하고자 하였다.

\section{재료 및 방법}

\section{실험재료 및 국수의 제조}

쌀은 도정한 백미와 현미를 농협, 소금은 천일염을 오프라 인 마켓에서 구매하여 사용하였다.

발효 현미 국수의 제조는 현미를 효모(Saccharomyces cereviseae IFO-2363)를 사용하여 발효한 다음 이를 분쇄하여 발효 현미가루를 준비하였다. 발효 현미가루에 물과 소금을 첨가하 여 Table 1의 배합비로 배합한 다음 반죽하였다. 반죽한 현미 반죽은 30 $35^{\circ} \mathrm{C}$ 의 온도에서 6시간 숙성하여 성형기에 반죽을 성형한 다음 제면기를 사용하여 발효 현미 국수를 제조하였 다. 국수의 제조는 SM 제분에서 제조하였다. 대조구로서는 백 미를 하였으며, 본 실험에 사용한 국수는 백미 국수(WN), 발 효 백미 국수(FWN), 현미국수(BN), 발효 현미국수(FBN)의 총 4 종을 제조하여 사용하였다.

\section{일반성분 분석}

일반성분 분석은 제조된 쌀 국수를 A.O.A.C 법[1]에 따라 조단백질은 Kjeldahl법, 조지방은 Soxhlet 추출법, 조회분은 직

Table 1. Mixing ratio used in rice noodle dough processing

\begin{tabular}{lccc}
\hline Samples & $\begin{array}{c}\text { Rice } \\
\text { flour }(\mathrm{g})\end{array}$ & $\begin{array}{c}\text { Salt } \\
(\mathrm{g})\end{array}$ & $\begin{array}{c}\text { Water } \\
(\mathrm{l})\end{array}$ \\
\hline White rice noodle $(\mathrm{WN})$ & 75 & 0.7 & 25 \\
Fermented white rice noodle $(\mathrm{FWN})$ & 75 & 0.7 & 25 \\
Brown rice noodle (BN) & 75 & 0.7 & 25 \\
Fermented brown rice noodle (FBN) & 75 & 0.7 & 25 \\
\hline
\end{tabular}

접 회화법으로 정량하였으며, 탄수화물은 시료 전체 무게에서 수분함량, 조단백 질, 조지방, 조회분을 뺀 나머지 값으로 표시 하여 나타내었다. 수분 함량 측정은 $105^{\circ} \mathrm{C}$ 상압 건조법을 통하 여 측정하였다.

\section{색도분석}

색도분석은 색차계(UltraScan XE, HunterLab, USA)를 이 용하여 Hunter값의 명도 $(\mathrm{L})$, 적색도 $(\mathrm{a})$, 황색도 $(\mathrm{b})$ 를 측정하였 다. 이때 사용한 표준 색판은 백색판(L:97.29, $\mathrm{a}=-2.21, \mathrm{~b}=+2.37)$ 을 사용하였다. 실험은 5 회 반복하여 측정한 평균치로 나타내 었다.

\section{조리 국수의 중량, 부피, 함수율 및 국물의 탁도 측정}

조리 국수는 중량 $10 \mathrm{~g}$ 을 $300 \mathrm{ml}$ 의 끓는 물에 넣고 3 분간 조리한 후 건져내어 냉수에 1 분간 냉각시킨 후 10 분간 물을 뺀 무게로 계산하였다. 국수의 부피는 중량을 측정한 직후 500 $\mathrm{ml}$ 메스실린더에 $300 \mathrm{ml}$ 의 증류수를 담아 국수를 넣은 후 증 가하는 물의 부피로 계산하였다. 조리국수의 함수율은 조리 후 건져낸 국수의 중량에서 생국수의 중량을 빼고 다시 생국 수의 중량을 나눈 후 100 을 곱하여 구하였다. 조리 후 국물의 탁도는 UV-Vis spectrophotometer (UV mini 1240, shimazu, Japan)를 사용하여 $675 \mathrm{~nm}$ 에서 측정하여 그 흡광도를 나타내 었다[6]

\section{조리 국수의 texture 측정}

조리 국수 dough의 물리적 특성은 Rheometer (Compact100, sun scientific co., Ltd., Japan)를 경도(hardness), 부착정 (adhesiveness), 응집성(cohesiveness), 탄성(springiness), 검 성(gumminess), 부서짐성(brittleness)을 측정하였으며, 이때 Rheometer의 측정조건은 Table 2 와 같이 설정하였다. 사용된 시료의 크기는 cutter를 이용하여 중앙부를 $2.0 \times 2.0 \times 30 \mathrm{~mm}$ 의 크기로 잘라내어 Rheometer로 같은 시료를 두 번 누를 때 얻 어지는 texture meter curve를 분석하여 texture 측정치를 계 산하였다[3,8].

\section{조리국수의 관능평가}

조리 국수의 관능평가는 동아대학교 20-30대 30명을 대상

Table 2. Measurement conditions of Rheometer

\begin{tabular}{lc}
\hline Parameters & Conditions \\
\hline Table speed $(\mathrm{mm} / \mathrm{min})$ & 60.00 \\
Chart speed $(\mathrm{mm} / \mathrm{sec})$ & 50.00 \\
Critical dia $(\mathrm{mm})$ & 20.00 \\
Load cell $(\mathrm{kg})$ & 10.00 \\
Sample height $(\mathrm{mm})$ & 2.00 \\
Sample width $(\mathrm{mm})$ & 2.00 \\
Span length $(\mathrm{mm})$ & 30.00 \\
\hline
\end{tabular}


으로 색, 맛, 향, 조직감, 종합적인 기호도를 평가하였다. 평가 방법은 각 관능검사 항목에 대하여 평점 기호도 검사법으로 실시하였으며 각 항목별로 최고 7점에서 최저1점으로 7단계 평가하여 SAS program으로 통계 처리하였다. 시료는 각각의 쌀국수를 3 분간 조리하여 흐르는 물에 냉각시킨 후 건져서 2 분간 물기를 제거한 즉시 사용하였으며 조리국수는 평가시 마다 흰색접시에 $20 \mathrm{~g}$ 씩 담아 사용하였다[3].

\section{결 과}

\section{성분분석}

제조된 국수의 조단백질, 조지방, 탄수화물의 일반성분을 각각 $100 \mathrm{~g}$ 에 함유되어 있는 양으로 조사하였다(Table 3). 조단 백질을 분석한 결과 $\mathrm{WN}, \mathrm{BN}$ 에서 $5.7,5.8 \mathrm{~g}$ 의 함량을 나타내 었으나 발효 후 $\mathrm{FWN}, \mathrm{FBN}$ 은 각각 $6.3,6.5 \mathrm{~g}$ 으로 증가하였다. 조지방의 함량은 $\mathrm{WN}, \mathrm{BN}$ 은 $0.1,0.2 \mathrm{~g}$ 이었으나 발효 후 $\mathrm{FWN}$, $\mathrm{FBN}$ 은 0, $0.1 \mathrm{~g}$ 으로 각각 감소하였으며, 탄수화물의 함량은 $\mathrm{WN}, \mathrm{BN}$ 은 69.6, $66.4 \mathrm{~g}$ 을 나타내었으나, 발효 후 FWN, FBN은 63.8, $63.4 \mathrm{~g}$ 으로 각각 감소하였다. 따라서 백미와 현미 국수는 발효과정을 거치면서 조단백질은 증가하고 조지방과 탄수화 물의 함량은 감소하는 것을 확인하였으며, 백미와 현미의 일 반성분의 유의적인 차이는 나타나지 않았다.

그리고 수분의 함량은 $\mathrm{WN}, \mathrm{BN}$ 에서 $44.9,72.1 \%$, 발효 후 에 $\mathrm{FWN}, \mathrm{FBN}$ 에서는 $30.4,69.2 \%$ 을 각각 나타내어 발효 전 보다 수분의 함량은 낮았으며 또한 백미로 만든 국수가 현 미로 만든 국수보다 수분의 함량이 2 배 이상 높게 나타내었 다(Table 4).

색도분석

제조된 국수의 색도는 명도(L), 적색도(a), 황색도(b)로 나

Table 3. Compositions of rice noodle

\begin{tabular}{lrrrr}
\hline Proximate composition & WN & FWN & BN & FBN \\
\hline Carbohydrate $(\mathrm{g})$ & 69.6 & 63.8 & 66.4 & 63.4 \\
Crude protein $(\mathrm{g})$ & 5.7 & 6.3 & 5.8 & 6.5 \\
Crude fat $(\mathrm{g} / 100 \mathrm{~g})$ & 0.1 & 0.0 & 0.2 & 0.1 \\
\hline
\end{tabular}

타내었다(Table 5). 명도(L)는 $\mathrm{WN}, \mathrm{BN}$ 에서 $37.30 \pm 4.12$, $31.23 \pm 1.24$ 를 나타내었으며, 발효 후의 FWN, FBN은 $32.50 \pm$ $1.31,31.53 \pm 1.96$ 으로 백미로 만든 국수가 현미로 만든 국수 보다 보다 높게 나타났으며, 발효 후에 백미는 명도가 감소 하였으며, 현미는 유의적인 변화를 나타내지 않았다. 적색도 (a)는 $\mathrm{WN}, \mathrm{BN}$ 에서 - $1.79 \pm 0.27,0.36 \pm 0.61$ 을 나타내었으며, 발효 후의 FWN, FBN는 $0.24 \pm 0.30,0.60 \pm 0.39$ 로 현미가 백미 보다 높았으며 발효과정에서 그 값이 증가하였다. 황색도(b) 는 $\mathrm{WN}, \mathrm{BN}$ 이 $5.00 \pm 0.80,7.56 \pm 0.61$ 이었으며 발효 후에 $\mathrm{FWN}, \mathrm{FBN}$ 은 $7.25 \pm 0.57,7.00 \pm 0.73$ 으로 백미로 만든 국수에 서는 증가하였으나, 현미로 만든 국수에서는 유의적인 차이 를 나타내지 않았다.

\section{국수의 중량, 부피, 함수율 및 국물의 탁도}

백미와 현미를 발효하여 제조한 국수의 조리의 특성을 중 량, 부피, 탁도로 각각 조사하였다(Table 6). 조리한 국수의 중 량의 변화는 $\mathrm{WN}, \mathrm{BN}$ 에서 $11.83 \pm 0.31,14.13 \pm 0.20 \mathrm{~g}$ 이었으나, 발효 후에 FWN, FBN은 $13.57 \pm 0.50,13.00 \pm 0.20 \mathrm{~g}$ 을 나타내었 으며, 부피의 변화는 $W N, B N$ 에서 $318.67 \pm 1.15,325 \pm 0.58 \mathrm{ml}$ 이 었으며, 발효 후의 FWN, FBN은 $328.00 \pm 1.00,330.33 \pm 0.58 \mathrm{ml}$ 로 조리전보다 중량과 부피의 변화가 모두 증가하였다. 함수 율의 변화는 $\mathrm{WN}, \mathrm{BN}$ 은 $18.32 \pm 3.1,41.34 \pm 2.1 \%$ 이었으며, $\mathrm{FWN}, \mathrm{FBN}$ 은 각각 $35.72 \pm 5.0,30.00 \pm 2.0 \%$ 를 각각 나타내었다. 조리 후 국물의 탁도의 변화는 $\mathrm{WN}, \mathrm{BN}$ 에서 $0.39 \pm 0.01$, $0.22 \pm 0.02$ 를 나타내었으며 발효 후 FWN, FBN에서 $0.20 \pm 0.02$, $0.20 \pm 0.02$ 로 $\mathrm{WN}$ 에서 가장 높은 탁도를 나타내었으며 $\mathrm{BN}$, $\mathrm{FWN}, \mathrm{FBN}$ 에서는 유의적인 차이를 나타내지 않았다.

\section{국수의 조직감}

조리한 국수의 texture 측정은 경도(hardness), 부착정

Table 4. Moisture content of rice noodle

\begin{tabular}{lcccc}
\hline Proximate composition & WN & FWN & BN & FBN \\
\hline Moisture (\%) & $44.86 \pm 2.7$ & $30.35 \pm 2.4$ & $72.10 \pm 5.1$ & $69.62 \pm 4.1$ \\
\hline${ }^{1)}$ Mean \pm SD.
\end{tabular}

Table 5. Color parameters of rice noodles

\begin{tabular}{lccc}
\hline Samples $^{1)}$ & $\mathrm{L}^{2)}$ & $\mathrm{a}^{3)}$ & $\mathrm{b}^{4)}$ \\
\hline WN & $37.30 \pm 4.12$ & $-1.79 \pm 0.27$ & $5.00 \pm 0.80$ \\
FWN & $32.50 \pm 1.31$ & $0.24 \pm 0.30$ & $7.25 \pm 0.57$ \\
BN & $31.23 \pm 1.24$ & $0.36 \pm 0.61$ & $7.56 \pm 0.61$ \\
FBN & $31.53 \pm 1.96$ & $0.60 \pm 0.39$ & $7.00 \pm 0.73$ \\
\hline
\end{tabular}

\footnotetext{
${ }^{1)}$ Mean \pm SD.

${ }^{2)}$ Measures lightness and carries from 100 for perfect white to zero for black.

${ }^{3)}$ Measures redness when positive, gray when zero and greenness when negative.

${ }^{4)}$ Measures yellowness when positive and blueness when negative.
} 
Table 6. Cooking properties of cooked rice noodles

\begin{tabular}{lcccc}
\hline Samples $^{1)}$ & $\begin{array}{c}\text { Volume of } \\
\text { cooked noodle }\end{array}$ & $\begin{array}{c}\text { Turbidity } \\
(\text { absorbance })\end{array}$ & $\begin{array}{c}\text { Water absorption } \\
(\%)\end{array}$ & $\begin{array}{c}\text { Weight of cooked noodle } \\
(\mathrm{g})\end{array}$ \\
\hline WN & $318.67 \pm 1.15$ & $0.39 \pm 0.01$ & $18.32 \pm 3.1$ & $11.83 \pm 0.31$ \\
FWN & $328.00 \pm 1.00$ & $0.20 \pm 0.02$ & $35,72 \pm 5.0$ & $13.57 \pm 0.50$ \\
BN & $325.67 \pm 0.58$ & $0.22 \pm 0.02$ & $41.34 \pm 2.1$ & $14.13 \pm 0.21$ \\
FBN & $330.33 \pm 0.58$ & $0.20 \pm 0.02$ & $30.00 \pm 2.0$ & $13.00 \pm 0.20$ \\
\hline
\end{tabular}

${ }^{1)}$ Mean \pm SD.

(adhesiveness), 응집성(cohesiveness), 탄성(springiness), 검 성(gumminess), 부서짐성(brittleness)으로 조사하였다(Table 7). 경도는 $\mathrm{WN}, \mathrm{FBN}, \mathrm{BN}, \mathrm{FBN}$ 에서 각각 $1623.08 \pm 165.51$, $835.71 \pm 7.08,3823.16 \pm 140.18,1112.70 \pm 48.87 \mathrm{~g} / \mathrm{cm}^{2}$ 으로 나타 내었다. 부착성은 유의적인 차이가 나타나지 않았다. 응집성 은 $\mathrm{WN}, \mathrm{FBN}, \mathrm{BN}, \mathrm{FBN}$ 에서 $76.95 \pm 5.71,74.32 \pm 6.25,74.41 \pm$ $2.83,69.94 \pm 1.86 \%$ 을 나타내어 발효에 따라 감소함을 확인하였 으며, 탄성은 $\mathrm{WN}, \mathrm{FBN}, \mathrm{BN}, \mathrm{FBN}$ 에서 $41.00 \pm 9.90,74.26 \pm 1.28$, $65.87 \pm 3.40,79.44 \pm 2.07 \mathrm{~g}$ 으로 발효에 따라 증가함을 확인하였 다. 특히 백미는 약 2 배 정도의 탄성의 변화를 나타내었다. 검성은 $\mathrm{WN}, \mathrm{FBN}, \mathrm{BN}, \mathrm{FBN}$ 에서 $416.70 \pm 41.70,258.80 \pm 29.67$, $653.28 \pm 51.53,323.61 \pm 12.75 \mathrm{~g}$, 부서짐성은 $\mathrm{WN}, \mathrm{FBN}, \mathrm{BN}, \mathrm{FBN}$ 에서 $339.01 \pm 71.11,243.95 \pm 42.78,784.49 \pm 72.95,389.74 \pm 40.20$ $\mathrm{g}$ 으로 나타내어 현미가 백미보다는 높은 값을 나타내었으며, 발효를 하였을 때 그 값이 감소함을 확인하였다.

\section{조리국수의 관능평가}

제조한 국수를 조리하여 색, 향, 맛, 조직감 및 종합적인 기 호도를 조사하였다(Table 8). 백미와 현미를 발효하여 제조한 국수에서 색은 $\mathrm{WN}, \mathrm{BN}$ 보다 발효 후인 $\mathrm{FWN}, \mathrm{FBN}$ 에서 2배
정도 높게 평가되었으며, $\mathrm{FWN}$ 이 $6.33 \pm 0.58$ 로 가장 높은 선호 도를 보였다. 향은 $\mathrm{WN}$ 과 $\mathrm{BN}$ 보다 발효 후에 증가하였으며 현미에서 높은 선호도를 보였다. 맛은 $\mathrm{WN}$ 에서 $1.33 \pm 0.58$ 로 낮은 평가를 받았으며, 발효 후에 맛의 선호도가 높게 나타내 었다. 조직감은 유의적인 차이를 나타내지 않았으나 발효 후 에 높게 나타내었으며, 종합적인 기호도는 현미가 백미로 만 든 국수보다 높은 평가를 받았으며, 발효 한 국수에서 높은 평가를 받았다. 따라서 $\mathrm{FBN}$ 이 모든 관능검사결과 가장 높은 평가를 확인할 수 있었다.

\section{고 찰}

최근 건강에 대한 관심이 증가하면서 건강기능성식품, 간편 편이식품, 식품안전 등의 중요성이 부각되고 있다[22]. 쌀은 우리나라의 대표적인 주식이며, 다양한 기능성을 가진 영양성 분을 가지고 있지만 밀과 다르게 다양한 식품가공품의 개발에 한계점을 가지고 있다. 따라서 오래 전부터 우리나라에서 경 사스런 일이 있을 때 건강 장수를 기원하고자 할 때 사용하기 도 하며, 현재는 밥, 빵과 더불어 주식에 해당하는 가공식품[7] 으로 알려져 있는데 국수는 쌀보다 조리의 편리성이 있어서

Table 7. Texture properties of rice noodles

\begin{tabular}{lcccc}
\hline Parameters $^{1)}$ & WN & FWN & BN & FBN \\
\hline Hardness $\left(\mathrm{g} / \mathrm{cm}^{2}\right)$ & $1623.08 \pm 165.51$ & $835.71 \pm 7.08$ & $3823.16 \pm 140.18$ & $1112.70 \pm 48.87$ \\
Adhesiveness $(\mathrm{g})$ & $0.00 \pm 0.00$ & $0.00 \pm 0.00$ & $0.00 \pm 0.00$ & $0.00 \pm 0.00$ \\
Cohesiveness (g) & $76.97 \pm 5.71$ & $74.32 \pm 6.25$ & $74.41 \pm 2.83$ & $69.94 \pm 1.86$ \\
Springiness (\%) & $41.00 \pm 9.90$ & $74.26 \pm 1.28$ & $65.87 \pm 3.40$ & $79.44 \pm 2.07$ \\
Gumminess (g) & $416.70 \pm 41.07$ & $258.80 \pm 29.67$ & $653.24 \pm 101.53$ & $323.61 \pm 12.75$ \\
Brittleness (g) & $339.01 \pm 71.11$ & $243.95 \pm 42.78$ & $784.49 \pm 72.95$ & $389.74 \pm 40.20$ \\
\hline
\end{tabular}

${ }^{1)}$ Mean \pm SD.

Table 8. Sensory evaluation of cooked noodles

\begin{tabular}{lcccc}
\hline Parameters $^{1)}$ & WN & FWN & BN & FBN \\
\hline Flavor & $2.00 \pm 1.00$ & $5.00 \pm 1.00$ & $3.33 \pm 0.58$ & $6.33 \pm 0.58$ \\
Color & $3.33 \pm 0.58$ & $4.67 \pm 0.58$ & $5.00 \pm 0.00$ & $5.33 \pm 0.58$ \\
Taste & $1.33 \pm 0.58$ & $4.67 \pm 0.58$ & $3.67 \pm 0.58$ & $5.67 \pm 0.58$ \\
Appearance & $4.00 \pm 0.00$ & $4.33 \pm 0.58$ & $4.67 \pm 0.58$ & $4.67 \pm 0.58$ \\
Overall acceptability & $1.67 \pm 0.58$ & $5.00 \pm 0.00$ & $3.67 \pm 0.58$ & $5.67 \pm 0.58$ \\
\hline
\end{tabular}

${ }^{1)}$ Each value represents the mean \pm SD of observations using hedonic scale of 1 (dislike very much) to 7 (like very much). 
요즘 현대인의 선호도가 높은 식품 중에 하나이다. 따라서 영 향학적 성분이 높은 쌀을 이용하여 쌀국수를 제조하고자 하였 다. 하지만 쌀은 쌀가루는 밀가루와 달리 글루텐을 가지고 있 지 않기 때문에 국수 제조시 구조 형성능이 낮아 가공적성이 좋지 못하므로 밀가루를 대체하는데 많은 제약이 있다[22]. 이 러한 문제를 해결하기 위하여 쌀을 미생물을 이용하여 발효하 여 국수제조를 하였으며, 또한 일반 백미보다 영양성분이 높 은 현미[14]를 이용하여 쌀이 가지는 영양학적 성분을 가지면 서 주식의 대체 가공식품을 개발하고자 하였다.

국수의 제조는 백미와 현미를 각각 발효하여 국수를 $\mathrm{WN}$, $\mathrm{FWN}, \mathrm{BN}, \mathrm{FBN}$ 으로 제조하여 이의 물리적 특성을 비교하였 다. 일반성분의 분석결과 현미로 만든 국수가 백미로 만든 국 수보다 조단백질, 조지방의 함량은 약간 낮게 나타났으며, 발 효 후에 그 변화가 조단백질은 증가를 보였으나 조지방은 감 소를 하였다. 또한 탄수화물의 변화는 백미가 현미보다 낮게 나타났지만 발효 후에 감소하였지만 현미와 백미에서 그 함량 의 차이가 나타나지 않아 미생물에 의해 발효과정에서 당과 지방의 소모가 일어나 미생물의 대사에 이용되며 또한 대사산 물로서 단백질의 합성이 일어난 것으로 사료된다. 수분의 함 량은 현미가 백미보다 약 2 배정도 높게 나타났으며, 발효하였 을 때 수분의 함량은 약간 감소하여 현미로 만든 국수가 수분 함량이 상대적으로 조직감이 부드러운 것으로 사료된다.

색도의 분석은 백미와 현미에서 발효에 따른 유의적인 차이 는 나타나지 않았지만 현미가 명도는 낮게 나타났으며 이에 반해 적색도와 황색도는 높게 나타났다. 또한 발효하였을 때 색이 짙은 현미의 경우는 황색도는 감소하였으며, 명도와 적 색도는 약간 증가하였지만 유의적인 차이는 나타나지 않았다. 백미의 경우는 명도는 감소하였지만 적색도와 황색도는 증가 하는 것을 확인 할 수 있어, 이는 미생물에 의한 당의 소모 및 다양한 대사산물의 생성 때문으로 사료된다.

제조된 국수의 조리시 중량과 부피는 조리되었을 때 증가하 는 경향을 보였으며, 이는 다른 조리면들과 같은 결과를 나타 내었다. 또한 쌀로 만든 국수는 조리과정에서 전분 용출량이 많다고 알려져 있는데[12], 이는 소실에 의한 국물의 탁도와 연관성을 가지고 있어서 대조구로 사용한 $\mathrm{WN}$ 은 탁도가 가장 높았으며, 또한 조리 후 중량도한 다른 국수에 비하여 낮음을 확인하였다.

제조된 국수의 texture는 백미를 발효하였을 때 면의 경도, 응집성, 검성, 부서집성은 감소하였으며, 탄성은 증가하였다. 그리고 부착성은 유의적인 차이를 나타내지 않았다. 이는 조 리시에 수분의 흡수율이 증대됨에 따라 조직이 부드러워지며 [13], 또한 발효에 따라 탄성이 증대되는 것으로 사료된다. 관 능검사결과 쌀을 발효하였을 때 색, 향, 맛, 조직감 및 전체적 인 기호도가 증대되었으며, 백미보다는 발효 현미를 이용한 국수에서 가장 높은 평가를 확인하였다. 따라서 쌀이 가지는 영양성분을 다량 함유하고 있는 현미를 이용한 발효 현미국수
가 쌀을 이용한 국수제조의 단점을 개선하고, 또한 현대인의 기호도와 간편성에 적합한 가공식품으로의 개발에 적합하다 고 사료된다.

\section{감사의 글}

본 연구는 농림수산식품부(농림, 식품, 수산) 기술개발사업 (610003-03-1-SB110)의 연구비지원에 의해서 수행되었습니다. 실험 중 발효 현미 면을 제조해 준 (주)SM 제분의 대표이사 김수민님께 감사드립니다.

\section{References}

1. A.O.A.C. 1984. Official methods of analysis., 15th eds., Association of Official Analysis Chemists, Washington D.C., USA.

2. Chun, H. S., You, J. E., Kim, I. H. and Chom, J. S. 1999. Comparative antimutagenic and antioxidative activities of rice with different milling fractions. J. Korean Soc. Food Sci. Nutr. 31, 1371-1377.

3. Chong , H. S. and Park, C. S. 2003. Quality of noodle added powder of Opuntia Ficus-indica var. Saboten. Korean J. Food Preserv. 10, 200-205.

4. Delcour, J. A. and Hoseney, R. C. 2010. Principles of cereal science and technology (3rd ed). AACC Inte W National, Inc., St. Paul, MN, USA. pp. 229-235.

5. Ha, T. Y. 2002. Nutritional and functional properties of rice. Proceedings of the Korean Society of Postharvest Science and Technology of Agricultural Products Conference. pp. 64-71.

6. Jeong, C. H., Kim, J. H., Cho, J. R., Ahn, C. G. and Shim, K. H. 2007. Quality characteristics of wet noodles added with Korean paprika powder. J. Korean Soc. Food Sci. Nutr. 36, 779-784.

7. Jim, S. Y., Kang, M. Y. and Kim, M. H. 2008. Quality characteristics of noodle added with browned oak mushroom (Lentinus edodes). Korean J. Food Cookery Sci. 24, 665-671.

8. Johnston, M. R. 1979. Sensory evaluation methods for the practicing food technologist. 1st short course committee, pp. 1-6.

9. Jung, B. M., Park, S. O. and Shin, T. S. 2009. Development and quality characteristics of rice noodles made with added Capsosiphon fulvescens Powder. Korean J. Food Cookery Sci. 25, 180-188.

10. Kang, M. Y., Lee, Y. R., Koh, H. J. and Nam, S. H. 2004. Antioxidantive and antimutagenic activity of ethanolic extracts from giant embroynic rice. J. Korean Soc. Appl. Biol. Chem 47, 61-66.

11. Kim, B. K., Park, J. E. and Genuine, Z. 2011. Effects of semolina on quality characteristics of the rice noddles. Food Eng. Prog. 15. 56-63.

12. Kim, T. H. 2010. Rice processing industry and product status. Proceedings of the Korean Society of Postharvest 
Science and Technology of Agricultural Products Conference, Korea. 181-194.

13. Kim, Y. S. 1998. Quality of wet noodle prepared with wheat flour and mushroom powder. Korean J Food Sci. Technol. 30, 1373-1380.

14. Ko, M. R., Choi, H. J., Han, B. K., Yoo, S. S., Kim, H. S., Choi, S. W., Hur, N. Y., Kim, C. N., Kim, B. Y. and Baik, M. Y. 2011. Antioxidative components and antioxidative capacity of brown and black rices. Food Eng. Prog. 15, 195-202.

15. Na, G. S., Lee, S. K. and Kim, S. Y. 2007. Antioxidative effects and quality characteristics of the rice cultivated by organic farming and ordinary farming. J. Korean Soc. Appl. Biol. Chem 50, 36-41.

16. Park, B. H., Jeon, E. R., Kim, S. D. and Cho, H. S. 2010. Quality characteristics of dried noodle added with lotus leaf powder. Korean F. Food Culture 25, 225-231.

17. Park, G. S. and Kim, J. Y. 2010. Quality characteristics of rice noodles with added allium vicitorialis powder. Korean J. Food Cookery Sci. 26, 772-780.
18. Park, J. H., Ko, S. H. and Yoo, S. S. 2010. Quality characteristics of wet noodles added with freeze-dried Maesangi powder. Korean J. Food Cookery Sci. 26, 831-739.

19. Park, S. I. and Cho, E. J. 2004. Quality characteristics of noodle added with Chlorella extract. Korean J. Food Nutr. 17, 120-127.

20. Sohn, H. Y., Kwon, C. S., Son, K. H., Kwon, G. S., Kwon, Y. S., Ryu, H. Y. and Kum, E. J. 2005. Antithrombosis and antioxidant activity of methanol extract from different brands of rice. J. Korean Soc. Food Sci. Nutr. 34, 593-598.

21. Stinissen, H. M., Prumans, W. J. and Carlier, A. R. 1983. Occurrence and immunological relationships of lectins in gramineous species. Planta 159, 105-111.

22. We, G. J., Cho, Y. S., Yoon, M. R., Shin, M. S. and Ko, S. H. 2010. Development of rice flour-based puffing snack for early childhood. Food Eng. Prog. 14, 322-327.

23. Yoon, S. S. 1991. Cultural history of Korea's noodles. Korean J. Dietary Culture 6, 85-94.

\section{초록 : 발효 백미와 현미를 이용한 국수제조 및 품질특성}

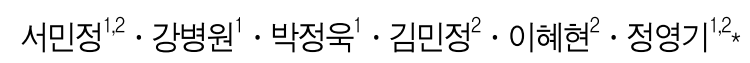

( ${ }^{1}$ 동아대학교 Medi-Farm 산업화 연구사업단, ${ }^{2}$ 동아대학교 생명공학과)

쌀을 이용하여 국수제조에 한계점을 개선하기 위하여 다양한 영양소를 함유한 현미를 사용하여 이를 발효한 후 국수를 제조하여 특성을 확인하였다. 국수는 백미와 현미를 이용하여 백미국수, 발효백미국수, 현미국수, 발효 현미국수를 각각 제조하여 사용하였다. 제조된 국수의 일반성분 분석 결과 발효하였을 때 조단백질 함량은 증가 되었으며, 조지방, 탄수화물의 함량은 감소하였다. 또한 수분의 함량은 현미국수가 백미보다 2 배 이상의 함량을 보였으며 발효하였을 때 약간 감소하는 것을 확인하였다. 색도는 발효함에 따라 약간의 변화는 있었으나 유의적 인 차이는 나타나지 않았다. 조리시 중량, 부피는 증가하였으나 백미로 만든 국수에서 그 변화가 가장 낮았으며, 조리된 국물의 탁도는 백미로 만든 국수에서는 높게 나타났지만 다른 국수에서는 일정한 탁도를 나타내었다. 조 리된 국수의 texture은 조리시에 수분의 함유로 조직이 부드러워짐에 따라 대부분 감소되었으나, 발효함에 따라 탄성도는 증대되었다. 따라서 영양학적 성분을 다량 함유하는 현미를 이용한 발효현미국수를 제조함으로서 쌀을 이용한 국수제조의 단점을 개선하고 현대인의 기호도에 적합한 쌀 가공식품으로의 개발이 가능하다고 사료된다. 